\title{
Evaluasi Kualitas Website Pemerintah Daerah Dengan Menggunakan WebQual 4.0 Pada Instansi Pemerintahan ABC
}

\author{
M.Afriansyah ${ }^{1)}$; Andi Sunyoto ${ }^{2)}$; Asro Nasiri ${ }^{3)}$ \\ ${ }_{1,2,3)}$ Magister Teknik Informatika, Universitas Amikom Yogyakarta \\ 1) afriansyah7901@students.amikom.ac.id, ${ }^{2)}$ andi@amikom.ac.id, ${ }^{3)}$ asro@amikom.ac.id
}

\begin{abstract}
The purpose of website quality evaluation is helping $A B C$ Government Institution to determine the significant influence of usability, information quality, and service interaction as a whole and partially. The research examines the relationship of usability, information quality, and service interaction in influencing the quality of the website in accordance with the reference webQual 4.0, by distributing questionnaires data processed using SPSS and analyzed by multiple regression analysis methods. The results of the analysis of all questions in the questionnaire were valid and reliable, the Cronbach alpha value for each statement $>0.1875$. The influence of X1 usability, $X 2$ information quality, and $X 3$ service interaction variables on website $Y 1$ quality is $63.8 \%$. The value of Adjusted $R$ Square is 0.407 or $40.7 \%$ the influence of independent variables on the dependent variable. In this study, the regression model equation is $Y=0.96+0.517 X 1+0.754 X 2+0.760 X 3$. The evaluation of website quality should be done on dimensions or variable usability. Thus, the respondents feel less understanding or have inconvenience in operating the website, and also find some difficult to explore the website.
\end{abstract}

Keywords: Evaluation, WebQual, Regression

\section{PENDAHULUAN}

Website merupakan salah satu layanan atau fasilitas yang ditawarkan oleh internet lebih banyak digunakan, dan layanan lainnya. situs akan memiliki kualitas konten informasi dan kemudahan bagi pengguna dimasukkan ke dalam penggunaannya untuk mendapatkan informasi yang dibutuhkan. Mengingat ini, perlu untuk menganalisis faktor-faktor yang dapat mempengaruhi kualitas dari sebuah situs web.

Definisi "E-Government refers to the use of information and communications technologies to improve the efficiency, effectiveness, transparency and accountability of government" [1]. Dengan kata lain, egovernment didefinisikan upaya sebagai untuk menggunakan dan efisien penggunaan telematika untuk meningkatkan efisiensi dan biaya administrasi yang efektif, menyediakan berbagai layanan kepada publik yang lebih baik, menyediakan akses ke informasi kepada masyarakat luas, dan untuk membuat pemerintahan yang lebih bertanggung jawab (accountable) dan transparan kepada publik

Website sebagai sarana media informasi, komunikasi, dan publikasi yang bisa mempengaruhi persepsi klien atau masyarakat umum mengunjungi situs web. Kualitas website menunjukkan evaluasi dan kunjungan terhadap sebuah website dapat mengubah website citra perusahaan terhadap persepsi pelanggan.

Bahwa pada dasarnya seseorang menggunakan situs layanan untuk menemukan informasi dengan cepat dan mudah didapat. Pengguna puas jika website dibuka layanan sesuai dengan persepsi kualitas layanan informasi yang Anda merasa dan tingkat harapan masa depan. Penggunaan dan kegunaan kunjungan ke situs web pada seberapa baik dan seberapa efektif berfungsi pengguna dapat menavigasi adalah salah satu faktor kunci dari kualitas website layanan. Evaluasi menjadi salah satu mencoba dalam meningkatkan pelayanan dan pengembangan yang mengacu dalam aturan daerah pada nomor 9 tahun 2012 yaitu tentang melayani masyarakat, kewajiban dalam menyelenggara untuk melakukan penilaian prestasi kerja yang secara rutin sebagai bahan untuk dievaluasi dalam peningkatan kualitas layanan masyarakat atau publik. Kualitas layanan website adalah kerangka yang digunakan dalam penelitian ini adalah WebQual 4.0 yang merupakan pengembangan dari servqual yang digunakan biasanya untuk mengukur kualitas layanan. Pendekatan instrumen WebQual dan pentingnya persepsi pengguna. Jika WebQual 1,0 menekankan analisis kualitas kekurangan layanan informasi dan interaksi WebQual 2.0 
Sebaliknya, lebih besar penekanan pada analisis interaksi, tetapi secara signifikan kurang dalam analisis kualitas informasi. Kedua instrumen yang dinilai untuk diterapkan pada studi tentang kualitas situs lelang online [2]. Dalam hasil penelitian yang mengetahui analisis kualitas website diklasifikasikan menjadi tiga area fokus yang berbeda, yaitu: Kualitas website, Kualitas informasi yang diberikan dan kualitas interaksi yang ditawarkan oleh layanan. Hasil penelitian ini dikenal sebagai WebQual 3.0. Analisis lebih lanjut dari kinerja WebQual 3.0. Model pendekatan 4.0 WebQual yang akhirnya menggantikan dimensi yang pertama, yaitu kualitas situs dalam dimensi kegunaan (kemudahan penggunaan). [2].

\section{TINJAUAN PUSTAKA \\ 2.1 Webqual}

WebQual merupakan metode yang salah satunya yaitu pengukuran kualitas website yang mengembangkannya. WebQual berdasarkan konsep Quality Function Deployment (QFD) adalah proses yang didasarkan pada "suara pelanggan" dalam mengimplementasikan

dan

mengembangankan suatu jasa atau produk. Konsep QFD, WebQual didasarkan pada persepsi pengguna akhir (end user) ke situs web. WebQual dibuat pada tahun 1998 dan yang telah mengalami perkembangan dalam perubahan kategori persiapan dan biji-bijian memiliki pertanyaan. WebQual versi terbaru adalah 4.0. WebQual 4.0 adalah ukuran untuk mengukur kualitas sebuah website didasarkan pada instrumen, alat penelitian yang dapat diklasifikasikan ke dalam empat variabel: kemudahan penggunaan, informasi yang berkualitas, Kualitas Interaksi Service, Umum. Dari empat variabel tersebut terdiri dari 23 butir pertanyaan. Variabel Usability dikaji berdasarkan hubungan antar manusia dan komputer dan tentang makhluk kegunaan web, antara lain, kemudahan navigasi, kecukupan desain dan gambar disajikan kepada pengguna. Kualitas penggunaan meliputi kemudahan untuk belajar, mudah digunakan, sangat menarik, menyenangkan secara visual, memiliki kompetisi yang baik, memberikan pengalaman baru [2].

\section{$2.2 \quad$ Evaluasi}

Evaluasi merupakan suatu proses atau kegiatan pemilihan, pengumpulan, analisis dan penyajian informasi yang dapat digunakan sebagai dasar pengambilan keputusan serta penyusunan program selanjutnya. Pengukuran diartikan sebagai kegiatan membandingkan hasil pengamatan dengan kriteria, penilaian (assessment) merupakan kegiatan menafsirkan dan mendeskripsikan hasil pengukuran, sedangkan evaluasi merupakan penetapan nilai atau implikasi perilaku [3].

\subsection{Pengertian Analisis Regresi}

Analisis regresi adalah suatu analisis yang dilakukan terhadap dua variabel yaitu variabel independen (prediktor) dan variabel dependen (respon) untuk mengetahui apakah ada pengaruh variabel prediktor terhadap variabel respon sehingga variabel respon dapat diduga berdasarkan variabel prediktornya. Berdasarkan jumlah variabel independennya, analisis regresi linier dibagi menjadi dua macam yaitu, analisis regresi linier sederhana dan analisis regresi linier ganda. Pada analisis regresi linier sederhana, jumlah variabel independen yang digunakan sebagai penduga variabel dependen adalah satu. Sedangkan pada analisis regresi linier ganda, jumlah variabel independen yang digunakan sebagai penduga variabel dependen adalah lebih dari satu [4].

\section{METODE PENELITIAN}

Jenis penelitian yang akan dilakukan berupa deskriptif dengan pendekatan Kuantitatif yang bertujuan untuk membuat gambar atau deskriptif dari sebuah situasi obyektif.

\subsection{Metode Pengumpulan Data a. Kuesioner}

Kuesioner adalah serangkaian pertanyaan tertulis yang digunakan dalam memperoleh informasi dari responden tentang hal-hal yang diketahui atau dialami. Kuesioner ini dirancang untuk mendapat objek informasi tertulis dari responden dalam kaitannya dengan tujuan penelitian.

\section{b. Interview}

Interview adalah proses memperoleh informasi untuk tujuan penelitian sebagai pertanyaan respon langsung antara peneliti dan diwawancara atau pihak yang terkait. Teknik ini digunakan untuk data yang tidak menjawab kuesioner atau menjawab masih sangat diragukan. 


\section{c. Observasi}

Peneliti melakukan observasi langsung ke fokus peneliti untuk melihat dalam jarak yang dekat dari kegiatan yang dilakukan. Proses ini dimulai dengan mengidentifikasi pengamatan tempat untuk studi, gambaran umum diperoleh sehingga penelitian dalam tentang sasaran untuk mendapatkan informasi permasalahan serta tujuan dalam penelitian yang dilakukan.

\subsection{Metode Analisis Data}

Tahapan pertama, identifikasi variabel penelitian, sesuai dengan acuan metode web qual, identifikasi variabel yang digunakan dari kualitas website.

Variabel Independent yaitu :

Kemudahan (usability)....

Kualitas informasi (information quality)..(X2)

Service Interaction.

Variabel Dependent yaitu :

Kualitas Website (Overall)

Semua variabel yang diukur melalui indikator-indikator menggunakan skala Likert, dari angka 1 untuk pertanyaan atau pernyataan sangat tidak setuju sampai angka 4 dalam pertanyaan atau pernyataan sangat setuju.

Penentuan jumlah responden berdasarkan jumlah populasi pegawai yang ada di Instansi Pemerintahan yaitu sebanyak 400 populasi. Sampel yang diambil menggunakan rumus slovin persamaan (1):

Jumlah pegawai $\mathrm{N}=400$

$\mathrm{n}=\frac{N}{1+N e^{2}}$
$\mathrm{n}=\frac{400}{1+400 \times 0.1^{2}}=80$ responden

Tingkat signifikansi untuk uji dua arah $\mathrm{e}=$ $10 \%=0,1$. Sehingga nilai $r$-tabel diperoleh sebesar $=0,1852$.

Pengambilan data diserahkan pada pihak Instansi Pemerintahan ABC sebanyak 80 kuesioner untuk diisikan oleh 80 pegawainya. Adapun metode penarikan sampel yang digunakan pada penelitian ini adalah purposive sampling. Purposive sampling yaitu penarikan sampel berdasarkan pertimbangan dimana sampel yang dipilih didasarkan pada kriteria-kriteria tertentu [5].

Penyebaran kuesioner mengakibatkan hasil data dirasa perlu dilakukan pengujian valid tidaknya data. Selain itu, untuk itu perlu juga dilakukan pengujian konsistensi responden dalam menjawab. Maka dari itu, dilakukan uji reliabilitas dan validitas untuk meguji kevalidan dan konsistensi responden dalam menjawab dan kesesuaian dengan penelitian. Uji validitas dan reliabilitas yang sesuai. Pengujian dilakukan untuk menjaga validitas dan reliabilitasnya. Selain itu, untuk mengatasi pengaruh dari pengguna alat ukur, maka pengguna harus meningkatkan kemampuannya dalam menggunakan alat ukur tersebut [6]. Uji reliabilitas adalah pengujian untuk mengukur suatu kuesioner yang merupakan indikator dari variabel atau konstruk. Suatu kuesioner dikatakan reliabel atau handal jika jawaban seseorang terhadap pernyataan adalah konsisten atau stabil dari waktu ke waktu [7].

Metode analisis untuk mengetahui hubungan berpengaruh tidaknya variabel independen terhadap variabel dependen dilakukan dengan analsisi regresi. Digunakan analisis regresi linier berganda ini adalah untuk menilai keadaan atau peristiwa dimana (naik atau turunnya) variabel dependen, jika dua atau lebih variabel dependen sebagai predictor dinaik turunkan nilainya. Regresi linier berganda Persamaan (2)

$Y=a+\beta_{1} X_{1}+\beta_{2} X 2+\varepsilon$

(2)

\section{HASIL DAN PEMBAHASAN}

\subsection{Uji Validitas}

\section{Tabel 1. Uji validitas}

\begin{tabular}{|c|c|c|c|c|c|}
\hline \multicolumn{6}{|c|}{ Item-Total Statistics } \\
\hline & $\begin{array}{l}\text { Scale } \\
\text { Mean if } \\
\text { Item } \\
\text { Deleted }\end{array}$ & $\begin{array}{c}\text { Scale } \\
\text { Variance } \\
\text { if Item } \\
\text { Deleted }\end{array}$ & $\begin{array}{c}\text { Correc } \\
\text { ted } \\
\text { Item- } \\
\text { Total } \\
\text { Correl } \\
\text { ation }\end{array}$ & $\begin{array}{c}\text { Squa } \\
\text { red } \\
\text { Multi } \\
\text { ple } \\
\text { Corre } \\
\text { lation } \\
\end{array}$ & $\begin{array}{c}\text { Cronbach's } \\
\text { Alpha if } \\
\text { Item } \\
\text { Deleted }\end{array}$ \\
\hline Usability & 83.983 & 86.295 & .489 & & .941 \\
\hline Usability & 83.983 & 85.267 & .544 & & .940 \\
\hline Usability & 84.495 & 84.217 & .554 & & .941 \\
\hline Usability & 83.970 & 85.694 & .658 & & .939 \\
\hline Usability & 84.433 & 84.480 & .694 & & .938 \\
\hline Usability & 83.820 & 87.427 & .506 & & .941 \\
\hline Usability & 84.183 & 83.373 & .694 & & .938 \\
\hline Usability & 84.283 & 82.959 & .663 & & .939 \\
\hline Rata Usability & 84.131 & 84.625 & .960 & & .937 \\
\hline $\begin{array}{l}\text { Information } \\
\text { Quality }\end{array}$ & 84.245 & 87.280 & .420 & & .942 \\
\hline $\begin{array}{l}\text { Information } \\
\text { Quality }\end{array}$ & 84.108 & 83.653 & .697 & & .938 \\
\hline $\begin{array}{l}\text { Information } \\
\text { Quality }\end{array}$ & 84.158 & 85.108 & .598 & & .940 \\
\hline $\begin{array}{l}\text { Information } \\
\text { Quality }\end{array}$ & 84.433 & 84.480 & .694 & & .938 \\
\hline $\begin{array}{l}\text { Information } \\
\text { Quality }\end{array}$ & 84.158 & 84.655 & .667 & & .939 \\
\hline $\begin{array}{l}\text { Information } \\
\text { Quality }\end{array}$ & 84.208 & 85.492 & .632 & & .939 \\
\hline $\begin{array}{l}\text { Information } \\
\text { Quality }\end{array}$ & 83.995 & 84.786 & .657 & & .939 \\
\hline $\begin{array}{l}\text { Rata } \\
\text { Information } \\
\text { Quality }\end{array}$ & 84.189 & 84.784 & .956 & & .937 \\
\hline $\begin{array}{l}\text { Service } \\
\text { Interaction }\end{array}$ & 83.845 & 87.719 & .435 & & .941 \\
\hline $\begin{array}{l}\text { Service } \\
\text { Interaction }\end{array}$ & 83.908 & 87.127 & .458 & & .941 \\
\hline
\end{tabular}




\begin{tabular}{|l|r|r|r|r|r|}
\hline $\begin{array}{l}\text { Service } \\
\text { Interaction }\end{array}$ & 84.145 & 88.446 & .371 & $\cdot$ & .942 \\
\hline $\begin{array}{l}\text { Service } \\
\text { Interaction }\end{array}$ & 84.333 & 82.105 & .665 & $\cdot$ & .939 \\
\hline $\begin{array}{l}\text { Service } \\
\text { Interaction }\end{array}$ & 84.170 & 84.727 & .728 & $\cdot$ & .938 \\
\hline $\begin{array}{l}\text { Service } \\
\text { Interaction }\end{array}$ & 84.208 & 84.214 & .608 & $\cdot$ & .940 \\
\hline $\begin{array}{l}\text { Service } \\
\text { Interaction }\end{array}$ & 84.158 & 89.151 & .237 & $\cdot$ & .944 \\
\hline $\begin{array}{l}\text { Rata Service } \\
\text { Interaction }\end{array}$ & 84.108 & 85.892 & .909 & $\cdot$ & .938 \\
\hline $\begin{array}{l}\text { Kualitas } \\
\text { Website }\end{array}$ & 84.045 & 84.108 & .606 & $\cdot$ & .940 \\
\hline
\end{tabular}

Berdasarkan tabel diatas dapat disimpulkan untuk nilai dari setiap pernyataan adalah $>R$ tabel ialah 0,1852, jadi dapat dikatakan dari setiap pernyataan itu dinyatakan valid.

\subsection{Uji Reliabilitas}

Tabel 2. Uji reliabilitas

\begin{tabular}{|r|c|c|}
\hline \multicolumn{3}{|c|}{ Reliability Statistics } \\
\hline $\begin{array}{c}\text { Cronbach } \\
\text { 's Alpha }\end{array}$ & $\begin{array}{c}\text { Cronbach's Alpha } \\
\text { Based on Standardized } \\
\text { Items }\end{array}$ & N of Items \\
\hline .942 & .947 & 26 \\
\hline
\end{tabular}

Seluruh nilai koefisien Cronbach Alpha masing-masing variabel $>0,6$ sehingga item pernyataan yang terdapat dalam kuesioner dinyatakan reliabel [8].

Sehingga dari analisis uji reliabilitas diatas, nilai Koefisien Cronbach's Alpha 0,942 $>0,6$ sehingga data dinyatakan reliabel

\section{Tabel 3. Variabel entered/removed}

\begin{tabular}{|l|l|l|l|}
\hline \multicolumn{3}{|c|}{ Variables Entered/Removed $^{\text {a }}$} \\
\hline Model & \multicolumn{1}{|c|}{$\begin{array}{l}\text { Variables } \\
\text { Entered }\end{array}$} & $\begin{array}{c}\text { Variables } \\
\text { Removed }\end{array}$ & Method \\
\hline 1 & $\begin{array}{l}\text { Rata Service } \\
\text { Interaction, Rata } \\
\text { Usability, Rata } \\
\text { Information }\end{array}$ & & Enter \\
& $\begin{array}{r}\text { Quality } \\
\multicolumn{3}{|c|}{} & & \\
\hline\end{array}$ \\
a. Dependent Variable: Kualitas Website \\
b. All requested variables entered.
\end{tabular}

Diketahui pada kolom model hanya ada satu model regresi yang dihasilkan. Variabel yang digunakan yaitu ada variabel $\mathrm{X} 1, \mathrm{X} 2$, dan X3 serta tidak ada variabel yang dibuang atau bermasalah dan metode yang digunakan yaitu enter.

\subsection{Korelasi Antar Variabel}

Tabel 4. Kolerasi antar variabel

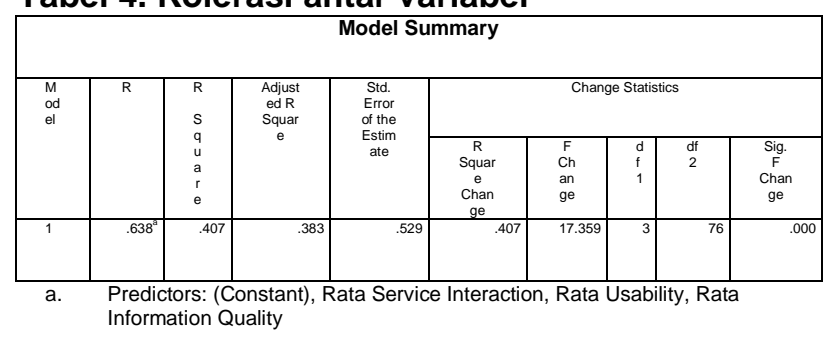

Model Summary digunakan untuk mengetahui tentang informasi yang pengaruh besarnya dari semua variabel independen terhadap variabel dependen. Besarnya pengaruh tersebut dapat diartikan dengan huruf atau simbol $\mathrm{R}$ atau kolerasi. Seperti yang bisa dilihat dalam tabel model summary yang dimana pada kolom $R$ adalah 0,638 artinya pengaruh variabel $\mathrm{X} 1, \mathrm{X} 2$ dan $\mathrm{X} 3$ terhadap $\mathrm{Y} 1$ sebesar 63,8\%. Berdasarkan analisis tersebut artinya usability, information quality dan service interaction mempengaruhi kualitas website sebesar $63,8 \%$. Kekuatan nilai variable $X$ dalam mempengaruhi variable $Y$ dapat dilihat dari nilai $R$ Square. Artinya kekuatan pengaruh dari variable usability, information quality dan service interaction terhadap kualitas website hanya sebesar $40,7 \%$, sisanya bisa saja dipengaruhi oleh variabel diluar dari penelitian ini.

\subsection{Model Prediksi Hasil Metode Regresi Linear Berganda}

Tabel 5. Model Prediksi hasil metode regresi linear berganda

\begin{tabular}{|c|c|c|c|c|c|c|}
\hline \multicolumn{7}{|c|}{ Coe } \\
\hline \multirow{2}{*}{\multicolumn{2}{|c|}{ Model }} & \multicolumn{2}{|c|}{$\begin{array}{l}\text { Unstandardized } \\
\text { Coefficients }\end{array}$} & \multirow{2}{*}{$\begin{array}{c}\text { Stand } \\
\text { ardize } \\
d \\
\text { Coeffi } \\
\text { cients } \\
\text { Beta }\end{array}$} & \multirow[t]{2}{*}{$t$} & \multirow[t]{2}{*}{$\begin{array}{l}\mathrm{Si} \\
\mathrm{g} .\end{array}$} \\
\hline & & $\mathrm{B}$ & $\begin{array}{l}\text { Std. } \\
\text { Error }\end{array}$ & & & \\
\hline \multirow[t]{4}{*}{1} & (Constant) & .096 & .570 & & .167 & .867 \\
\hline & $\begin{array}{l}\text { Rata } \\
\text { Usability }\end{array}$ & .517 & .356 & .316 & 1.455 & .150 \\
\hline & $\begin{array}{l}\text { Rata } \\
\text { Information } \\
\text { Quality }\end{array}$ & .754 & .366 & .452 & 2.063 & .043 \\
\hline & $\begin{array}{l}\text { Rata Service } \\
\text { Interaction }\end{array}$ & .760 & .308 & .338 & 2.842 & .002 \\
\hline
\end{tabular}

Nilai sig. dari variabel $\mathrm{X} 2$ dan $\mathrm{X} 3$ lebih kecil dari 0,1 artinya mempengaruhi variabel $Y$ secara parsial. Variabel $X 2$ atau information quality mempengaruhi kualitas website dalam hal penyajian informasi yang akurat, terpercaya, informasi selalu terbarui (up to date) serta informasi didalam website yang disediakan cukup terperinci dengan format yang sesuai. Variable $\mathrm{X} 3$ atau service interaction mempengaruhi kualitas website dalam hal reputasi website yang sangat baik, menciptakan rasa aman ketika berinteraksi dan terciptanya rasa personalia, dan memudahkan saat berinteraksi dengan komunitas atau web lain. Sedangkkan dari hasil variable usability tidak adanya signifikansi, karena hasil dari nilai sig sebesar $0,150>0,1$. 
Dari tabel Coefficient tersebut dapat disusun persamaan model regresi dengan melihat nilai-nilai pada kolom Coefficient B, yang dalam kasus ini model yang terbentuk yaitu: $Y=0,96+0,517 X 1+0,754 X 2+0,760 X 3$.

Dengan $\mathrm{X} 1=$ usability; $\mathrm{X} 2$ = information quality dan $\mathrm{X} 3=$ service interaction. Dari persamaan model regresi dapat dikatakan bahwa dalam penambahan setiap 1 point terhadap usability dapat mengakibatkan kualitas website akan menambah poin sebesar 0,517. Selanjutnya setiap penambahan 1 point information quality mengakibatkan kualitas website akan bertambah sebesar 0,754 point dan penambahan 1 point service interaction mengakibatkan kualitas website akan bertambah sebesar 0,760 point. Dengan kata lain item-item pada variabel independen yang dianalisis (usability, information quality, service interaction) memberikan kontribusi positif terhadap nilai pengukuran kualitas website dalam penelitian ini. Dari ketiga variabel tersebut kontribusi yang lebih besar terdapat pada variabel service interaction sebesar 0,760 dan diperoleh nilai Sig. 0,002< $\alpha=0,1$. Sehingga dari hasil penelitian ini dapat diterjemahkan bahwa, evaluasi dari kualitas website perlu dilakukan pada dimensi atau variable usability, responden merasa kurang dalam memahami atau memiliki ketidakmudahan dalam mengoperasikan website, dan merasa kesulitan karena menjelajahi website tersebut.

\section{PENUTUP}

Berdasarkan hasil analisis data dari penelitian diperoleh kesimpulan sebagai berikut: Dari persamaan regresi menunjukkan bahwa variabel independen yang dianalisis berupa item-item pertanyaan pada dimensi WebQual (usability, information quality, service interaction) berkontribusi positif terhadap kualitas website dalam penelitian ini, sehingga variabel atau dimensi usability, information quality, dan service interaction mempengaruhi kualitas website Instansi Pemerintah ABC. Namun, dari hasil penelitian diantara 3 variabel, evaluasi dari dimensi usability perlu dilakukan, karena responden merasa bahwa website kurang jelas dan sulit dipahami dalam berinteraksi dengan pengguna serta masih sulitnya menjalankan menu yang ada di website, maka sebaiknya untuk meningkatkan kualitas website dapat dilakukan seperti:
1. Dilakukan perbaikan dengan menampilkan menu yang mudah dipahami .

2. Memberikan desain website yang lebih sesuai dan menarik.

\section{DAFTAR PUSTAKA}

[1] E. Satriya, "Pentingnya Revitalisasi EGovernment Di Indonesia," in Prosiding Konferensi Nasional Teknologi Informasi \& Komunikasi untuk Indonesia 3-4 Mei, 2006, pp. 38-43.

[2] M. J. Roche, A. L. Pincus, M. R. Lukowitsky, K. S. Ménard, and D. E. Conroy, "An integrative approach to the assessment of narcissism," J. Pers. Assess., vol. 95, no. 3, pp. 237-248, 2013,

doi: 10.1080/00223891.2013.770400.

[3] H. Sitompul, Konsep Evaluasi Program Pembelajaran. 2018.

[4] T. L. Wasilaine, M. W. Talakua, and Y. A. Lesnussa, "Model Regresi Ridge Untuk Mengatasi Model Regresi Linier Berganda Yang Mengandung Multikolinieritas ( Studi Kasus: Data Pertumbuhan Bayi di Kelurahan Namaelo RT 001 , Kota Masohi ) Ridge Regression Model to Overcome Multiple Linear Regression with Multic," vol. 8, no. 1, pp. 31-38, 2014.

[5] T. A. Archandar, "Pengaruh Etika Kerja Terhadap Keterlibatan Kerja Dan Implikasinya Terhadap," J. Manaj. dan Pemasar. Jasa, vol. Vol. 3, pp. 27-52, 2010.

[6] F. Yusup, "Uji Validitas dan Reliabilitas Instrumen Penelitian Kuantitatif," J. Tarb. J. IIm. Kependidikan, vol. 7, no. 1, pp. 17-23, 2018, doi: 10.18592/tarbiyah.v7i1.2100.

[7] F. Saputra, "Analisis Pengaruh Kepercayaan, Keamanan, Kualitas Pelayanan, Dan Persepsi Akan Risiko Terhadap Keputusan Pembelian Melalui Situs Jejaring Sosial," J. Ekon. dan Kewirausahaan, vol. 15, no. 2, p. 79499, 2015.

[8] N. L. Nasution, "Analisis Loyalitas Kerja Pegawai Dinas Pendidikan Kabupaten Labuhanbatu," Ecobisma (Jurnal Ekon. Bisnis Dan Manajemen), vol. 6, no. 2, pp. 1-13, 2019, doi: 10.36987/ecobi.v6i2.1. 